\section{UK energy conservation}

\section{Lords say too little too late}

A HOUSE of Lords committee is soon to publish a stinging criticism of the British Government's policy on the rational use of energy. The committee's report, now in draft, complains that the government is spending too little on the encouragement of energy conservation, and with too little sense of purpose. But it defends the Government's policies on energy pricing against the recent rumblings of discontent from British industry and the Confederation of British Industry in particular.

The committee is one of several charged with the scrutiny of European Community legislation affecting Britain. To the Com munity, "rational use of energy" is a technical term embracing energy conservation, pricing policies and the encouragement of conversion from oil to other fuels.

The chief complaint against the British Government is that much of what it claims to be spending in the field - $£ 149$ million in 1981-82 - goes on domestic housekeeping (the insulation of public buildings) and that much of what is claimed as research and development is concerned with projects such as new aircraft engines, where energy conservation is a secondary consideration. The committee estimates that support for the rational use of energy in British industry amounts to no more than $£ 10$ million a year.

The committee's draft report also complains that the British Government's efforts in the field are poorly led and focused. Ignorance of Government schemes for helping with the cost of conversion to coal, or for supporting demonstration schemes, appears to be widespread, while the committee points out that industries such as brewing (which reduced energy consumption by 11 per cent in a single year and which is aiming at a further reduction of 20 per cent) have made savings largely off their own bat.

The committee asks that the Department of Energy's regional offices should be strengthened, that training courses in topics such as boiler technology (apparently dwindling) should be revivified and that the Government should organize itself to help British companies to benefit from a scheme (now being discussed by the European Community) by which rational-use investments would be forgiven 3 per cent of the cost of interest for the first five years. (This scheme is unlikely to be agreed before April.)

The committee's argument about energy pricing is more comforting for the Government. It accepts the view that energy prices charged by nationalized industries should be "realistic", but acknowledges the difficulty of telling what this means when account is taken of the cost of replacing existing fuel sources. It accepts only part of the recent complaint from British industry that energy costs are less elsewhere in the
European Community, saying that the nationalized industries should re-examine their tariffs for large users but that the problems of energy-intensive industries (such as metal processing and paper) may in the long run be insoluble and should in any case be dealt with as part of the Government's energy policy.

\section{$\mathrm{X}$-ray satellite}

\section{Launch to Thor}

THE European Space Agency (ESA) has swallowed its political pride and agreed that the X-ray satellite Exosat should be launched from the United States in May on a Thor-Delta rocket and not by means of Ariane. So much is clear from the schedule for the next five Ariane launches drawn up last week. The decision is a success for the astronomers lobbying in the past few months for a Thor-Delta launch.

The lobbying began when it became clear that delays in the Ariane programme could result in the physical deterioration of the satellite's detectors and other problems (such as loss of support staff) (see Nature 27 January, p.275). Astronomers had hoped to persuade ESA's council to release Exosat for an earlier Thor launch, but the decision has been left to the last possible moment. The National Aeronautics and Space Administration required notice by the end of February to be able to launch Exosat within its summer window. The Ariane L7 launch, for which Exosat had been planned, will have to follow the next Ariane, L6, and the council has now agreed that there would be too little slack for a summer launch of Exosat to be assured.

The new launch schedule for Ariane has been set after tests of the newly-designed turbopump gearing and lubrication system of the launcher's third stage. A fault in this component was responsible for the failure of the L5 launcher last May. That launch had been intended to place the two satellites in a geostationary transfer orbit and ESA has decided that Ariane L6, to be launched on 3 June, will attempt the same task with the European Communication Satellite ECS1, and Amsat, an amateur radio satellite.

Subsequent Ariane launches have been scheduled for 26 August, 4 November 1983 and January 1984. All three launches (L7 to L9) have been assigned to Intelsat $V$ satellites of the International Telecommunications Satellite Organization. Ariane L10, scheduled for March 1984, will be the first trial for Ariane 3. This, a more powerful version of the rocket, represents an important component in Europe's competition with the United States for the launcher market, and is intended to carry aloft a series of large commercial satellites, some of US origin.
Human embryo research INSERM to
ponder ethics

FRANCE is about to plunge itself into the joys - or miseries - of open debate on the ethics of biological and medical research, and particularly the ethics of research with human fetuses. The results, in a country of Roman Catholics and logicians, may be worth watching.

The first step was taken last week with the establishment, by ministerial decree, of France's first "national advisory committee on ethics for the life sciences and health research"'. This is the brainchild of Philippe Lazar, director of the medical research council (INSERM), who wanted to open up the previous INSERM ethics committee to the public, and to issues beyond INSERM's own particular problems.

Thus the new committee, to be headed by Professor Jean Bernard (a retired haematologist who is an adviser to Lazar), will study the question privately, advise the minister of health, and organize annual public debates on ethical issues in research - the first to take place towards the end of this year. It will also establish an international (and open) documentation and information centre, to compare treatment of ethical issues in different countries and provide a record of particular cases.

The membership of the committee is not yet fixed, but it will comprise four "moralists" (nominated by President Mitterrand) representing different philosophical groups; fourteen representatives of scientific institutions, of whom five will be from INSERM (and two of these from universities), three from the Centre $\mathrm{Na}$ tional de la Recherche Scientifique, two more from the universities (independent of research councils), one from the Institut Pasteur and the remainder from other in stitutions. Another fourteen members will come from affected ministries (such as health, education, and research and industry). Parliament, government and the research councils will each be able to present questions to the committee, which will then be duty-bound to answer; other bodies and members of the public may also pose questions, but the committee will not be obliged to reply.

The question of the moment is the treatment of human embryos and fetuses. Until recently, France had no explicit control of such work (except through local hospital ethical committees, and the special INSERM committee); lately INSERM established guidelines essentially identical to those of the British Medical Research Council (see Nature 300, 309; 1982), but these will only be treated as interim.

Meanwhile, the new committee will study the issue, while the ministry of health has published the "draft of a draft" of a law on the medical use of fetuses (avoiding 
the problem of in vitro fertilization, as the developing baby is technically an embryo to seven or eight weeks after fertilization,

This embryonic law is primarily concerned with the use of fetal tissue for medical purposes - such as fetal liver for controlling severe immune deficiency in a fewmonth-old baby, a technique practised (with about 50 per cent success) by Professor Jean-Louis Touraine of the Université Claud-Bernard, Lyon. The draft law demands that a donor fetus must be testified clinically dead by two doctors, and a fetus thereafter).

that the mother must agree, that only certain specified and regularly inspected institutions may do the work and that no money should change hands (for fear of sale of fetuses for profit).

The projected law has, however, met with fierce opposition from one quarter the INSERM research unit on fetal development and the neonate. The director of this unit, Professor Alexandre Minkowski, claims that the death of a fetus is very difficult to determine (cerebral activity being slight or undetectable in many cases).

Robert Walgate

Ordnance Survey

\section{Neither public nor private}

THE new British Environment Secretary, Mr Tom King, will be reconsidering the future of the Ordnance Survey following a recent vote in the House of Lords opposing the government's plan for the survey. Their lordships noted "with regret" the government's proposals to set up a Trading Fund to finance the survey along commercial lines. In the course of consultations, users of the Ordnance Survey ranging from the Royal Society to the Ramblers' Associaton had uniformly expressed their concern that the system would lead to a lowering of standards in the survey's work, which they regard highly.

The Ordnance Survey is a somewhat anomalous body: an independent government department without a minister in charge. In practice, it is looked after by the Department of the Environment (DoE) which drew up the plans. At present the survey is financed on a "vote" system, which means it requests - and gets funds directly from the Treasury. Under the government's plans, work considered to be in the national interest would be financed on a contract basis by DoE; the rest would have to pay its way. The Ordnance Survey would nevertheless remain a government department. The Royal Society, in its submission to DoE, said "excessive emphasis on the revenue require-

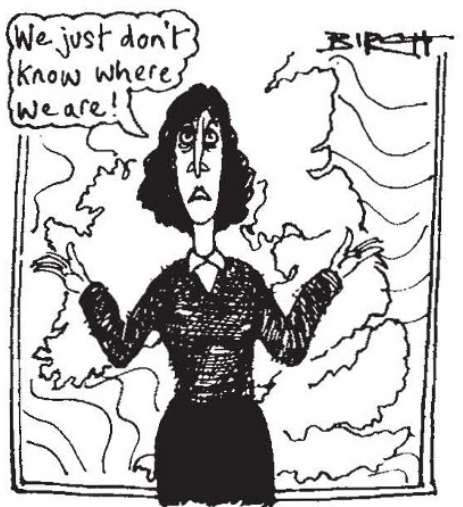

ment could lead to a loss of completeness and lowering of standards which would be detrimental to scientific research".

The Ordnance Survey has been successfully running joint ventures with private companies for some time, producing specialist maps. The small-scale maps beloved of countryside users are run on a separate trading account and cover their costs anyway. But large-scale maps, from $21 / 2$ to 50 inches to the mile, cannot be sold at a profit, and are currently subsidized by felt, like the users, that turning this subsidy into contract work would leave decisions on future Ordnance Survey projects such as producing digital maps of Britain - at the mercy of DoE officials. It was also pointed out that the director-general of the Ordnance Survey, as DoE's adviser on çartographic matters, would be in the difficult position of having to advise himself. The matter may now be referred to the new Advisory Board for the Ordnance Survey.

Because of the Ordnance Survey's governmental status, its public relations manager is not allowed to comment on the proposed changes. "We are just getting on with mapping Britain”, he said.

Tim Beardlsey

\section{More bio than tec}

THE new journal Bio/technology, with a slash or solidus across the " $t$ ", made its first appearance this week. The journal is published from New York by Nature Publishing Company Inc., which also publishes Nature in the United States. The two journals are, however, editorially independent.

The new journal is probably the most handsome setting yet in which chromatographic gel patterns and nucleotide sequences appear as a matter of routine. The editorial claim of the fastest peer-review system anywhere is well attested by the evidence in the first issue that none of the five research papers to appear was kept waiting more than 17 days for a decision.

The editor of the journal, Mr Christopher Edwards, says that his objective is to concentrate on the technology of biotechnology, but news items in the first issue are mostly concerned with cloning developments and novel monoclonal antibodies. Many readers will, however, be grateful for a review article explaining how about 70 per cent. The Lords apparently
Italy's nuclear power

\section{Action stations}

ITALY is to build six $1,000 \mathrm{MW}$ pressurized water reactors, under licence from the American Westinghouse corporation, the government announced last week, putting an end to years of political uncertainty.

Italy has three working power reactors at present, contributing just 1,200 MW between them to the Italian grid. This is only 3 per cent of the total electric power production of the country, which is dominated by oil-burning power stations. The new reactors will replace some of these oil-powered stations, the president of the Italian nuclear agency ENEA, Umberto Colombo, said on Monday.

The breakthrough has come through a new political will to reduce Italy's enormous oil bill, reduced local opposition and a law which gives central government the ultimate right of decision over the placement of nuclear plants.

However, despite regional approval, there is still some stiff local opposition to certain of the six sites, particularly in Lombardy and Puglia.

Meanwhile, some regions have shown themselves willing to accept nuclear power stations. The stage of formal approval has been reached in Piedmont, Lombardy and Puglia. Veneto, Umbria and Basilicata are less well advanced in the approval process.

It will take 14-18 months to select the three sites, and then 7-8 years to construct each reactor. The limited capacity of the Italian nuclear industry means it may be impossible to build all the reactors simultaneously. They may be constructed in two sets of three, but the first should be operating by 1992 .

Robert Walgate

bacteria can be used in tertiary oil recovery, while the first issue of the journal includes an analysis of US patents in biotechnology granted during 1982 and abstracts of recent patents.

The chief research article is an account of the nuclear nucleotide sequence of the smaller subunit of the chloroplast enzyme ribulose-1,5-phosphate carboxylase in wheat. Richard Broglie and associates at the Rockefeller University have shown that the smaller protein (eight copies of which appear together with eight copies of the larger protein generated within the chloroplast in the intact enzyme) is coded for by a multigene family in the nucleus.

There is also an account (by a group at the State University of New York at Stony Brook) of how synthetic 29-fluorophytosterols may be effective but safe insecticides because vertebrates lack the metabolic pathway that, in insects, dealkylates the steroid side-chain at C-24, thereby producing toxic fluoroacetate. On balance, Bio/technology has less overtly commercial information than might have been expected. 